einstein

Official Publication of the Instituto Israelita de Ensino e Pesquisa Albert Einstein

ISSN: 1679-4508 | e-ISSN: 2317-6385

\title{
Valuing tonsillitis manifestations in schoolchildren in Rio de Janeiro
}

\author{
Rafaela Valentim Goldenzon', Tiago Oliveira Lucas², Maria de Marilacc Lima Roiseman', \\ Marta Cristine Félix Rodrigues², Adriana Rodrigues Fonseca², \\ Sheila Knupp Feitosa de Oliveira² ${ }^{2}$ Andréa Valentim Goldenzon ${ }^{1}$ \\ Escola de Medicina Souza Marques, Fundação Técnico-Educacional Souza Marques, Rio de Janeiro, RJ, Brazil. \\ 2 Universidade Federal do Rio de Janeiro, Rio de Janeiro, RJ, Brazil.
}

DOI: 10.31744/einstein_journal/2022A06342

\section{ABSTRACT}

Objective: To evaluate the importance attributed to tonsillitis by guardians and their level of knowledge about the disease, correlating their management with their schooling and socioeconomic profiles. Methods: A quantitative, descriptive and observational crosssectional study involving students aged 5 to 17 years from state-owned and private schools. A questionnaire was applied on management of tonsillitis and knowledge about rheumatic fever, addressing demographic and socioeconomic data. Results: A total of 323 students were included, predominantly females (61.3\%), from state-owned schools $(77.1 \%)$, with a mean age of $9.7 \pm 0.3$ years. Among the guardians, $48.6 \%$ completed high school. Among the students $75.2 \%$ had at least one episode of odynophagia in the previous 12 months. Considering the previous 2 years, $89.8 \%$ reported this symptom. There was no collection of bacteriological specimens in $67.8 \%$, and in $83 \%$ if taking into account only the last episode, despite the search for medical care in most cases $(92.6 \%)$. The use of anti-inflammatory drugs was very frequent $(43.0 \%$ "always" and $42.4 \%$ "sometimes"). Among the guardians, $81.7 \%$ denied being aware of the relation between rheumatic fever and inappropriate treatment of odynophagia; $85.8 \%$ said they wished they had received more information. Conclusion: Although it is quite common in schoolchildren, tonsillitis is neglected by many guardians and health professionals, and the ignorance of its relation with rheumatic fever is practically universal, which may contribute to its high prevalence.

How to cite this article:

Goldenzon RV, Lucas TO, Roiseman MM, Rodrigues MC, Fonseca AR, Oliveira SK, et al. Valuing tonsillitis manifestations in schoolchildren in Rio de Janeiro. einstein (São Paulo). 2022;20:eA06342.

\section{Corresponding author: Andréa Valentim Goldenzon \\ Avenida Ernani Cardoso, 335 - Cascadura Zip code: 22261-030 - Rio de Janeiro, RJ, Brazil \\ Phone: (55 21) 2128-4943 \\ E-mail: andrea@goldenzon.com.br}

\section{Received on:}

Nov 26, 2020

\section{Accepted on:}

Abr 9, 2021

Conflict of interest:

none.

\section{Copyright 2022}

\section{INTRODUCTION}

Acute tonsillitis is a common disease caused by several viral and bacterial agents. Infection of the oropharynx caused by Streptococcus pyogenes requires specific identification and treatment due to the potential of triggering post-infectious complications. ${ }^{(1)}$ In Brazil, it is estimated that approximately 10 million cases of streptococcal tonsillitis occur every year, totaling 30,000 new cases of rheumatic fever, up to half of which can evolve with cardiac involvement. ${ }^{(2)}$ Despite this overwhelming estimate, no study was found specifically addressing the relevance attributed to tonsillitis or the population's knowledge about rheumatic fever and the management adopted by caregivers and physicians when facing tonsillitis.

The prevalence of rheumatic fever is the highest in individuals aged 5 to 15 years, and it is the leading cause of acquired heart disease in young adults in Brazil and many other developing countries. In 2015, the estimate of death from rheumatic heart disease was 319,400 people. ${ }^{(3)}$ The recent emergence of echocardiographic screening programs has shown a much higher prevalence 
of rheumatic heart disease in schoolchildren than previously described, suggesting estimates of incidence and prevalence of rheumatic fever in developing countries do not reflect the true impact of the disease. ${ }^{(2)}$ The major consequence of rheumatic heart disease for the health care system is reflected both in the frequent hospitalizations and required cardiac surgeries and in the functional impairment of these patients and their families. ${ }^{(4)}$ Recent guidelines from the World Health Organization (WHO) and the World Heart Federation (WHF) have committed to reduce by one-third the number of premature deaths from non-communicable diseases by $2030 .^{(5)}$ Rheumatic heart disease is a severe complication of streptococcal tonsillitis. Rheumatic fever is a disease whose prevention is simple and low cost, and is carried out through the application of benzathine penicillin in patients with tonsillitis caused by group A beta-hemolytic $S$. pyogenes, ${ }^{(6)}$ a bacterium responsible for triggering the disease in genetically predisposed individuals and for approximately $20 \%$ to $30 \%$ of cases of tonsillitis in pediatric patients. ${ }^{(7)}$

The main reasons for inadequate treatment are lack of information about the origin of the disease, poor choice or irregular use of antibiotics, besides indiscriminate use of anti-inflammatory and other symptomatic drugs to manage oropharyngeal infection without identifying the causative agent. Thus, the resolution of clinical manifestations occurs, but with perpetuation of bacterial proliferation, which may subsequently cause the development of rheumatic fever.

Despite the estimated 10 million streptococcal tonsillitis cases per year in Brazil,(2) no studies were found addressing its importance in the population or knowledge about its relation with rheumatic fever.

\section{OBJECTIVE}

To evaluate the importance attributed to oropharyngeal infection by the guardians and the level of knowledge about the disease, correlating the management with the school and socioeconomic profiles.

\section{METHODS}

This is a quantitative and descriptive cross-sectional study. The study was conducted based on an analysis of questionnaires completed during August 2018 by guardians of students aged 5 to 17 years, from two schools selected for their proximity to the educational institution of origin of the study. A total of 500 students in the chosen age group (120 from a private school and 380 from a state-owned school) received the set of documents consisting of the questionnaire (Table 1), a manual for filling it out, and an Informed Consent Form. The quantity of documents distributed was based on the proportion found between private and stateowned school students in the municipality of Rio de Janeiro, according to the Instituto Nacional de Estudos e Pesquisas Educacionais Anísio Teixeira (Inep). ${ }^{(8)}$ A total of 323 students were included, whose material was returned duly filled out within two weeks of receipt. Of those, 177 were excluded, $46(38.3 \%)$ from the private school, and $131(34.4 \%)$ from the state-owned school, for lack of response to the questionnaire.

The research project was submitted to and approved by the Ethics Committee of the Escola de Medicina Souza Marques da Fundação Técnico-Educacional Souza Marques, under protocol \# 2.834.886, and CAAE: 90753018.6.0000.5239.

For statistical analysis, the test of equality of two proportions was used to characterize the distribution of the relative frequency of each of the study variables. For the descriptive analysis of age, a $95 \%$ confidence interval was used.

The following data were collected: age, sex, school network (private or state-owned), schooling level of the guardian, family monthly income, and frequency of sore throat in the child over the past 12 months and in prior years, visits to the doctor for sore throat, associated symptoms, and their management of the symptom. In addition, the parents' knowledge about rheumatic fever and the desire to receive information about the disease were questioned.

\section{॥ RESULTS}

The guardians of 323 students returned the questionnaires duly completed within the stipulated deadline (Table 2). The mean age of the students was $9.7 \pm 0.3$ years, with a predominance of females $(61.3 \%)$ and individuals from state-owned schools (77.1\%). Regarding the guardians' schooling level, the majority was composed of individuals who completed secondary education (high school) $(48.6 \%)$. The families with income between zero and $\mathrm{R} \$ 1.254,00$ accounted for $32.2 \%$ of the sample $(\mathrm{p}=0.214)$. A minority of families had an income higher than $\mathrm{R} \$ 8.641,00$ (2.6\%).

Of the total respondents, only $24.8 \%$ stated their child had not had any episode of sore throat in the past 12 months $(p=0.079)$. For $31.0 \%$ of respondents, their child had a sore throat in the past 12 months once, and only $17.3 \%$ reported three or more episodes $(p<0.001)$. 
Table 1. Questionnaire sent to the students' guardians

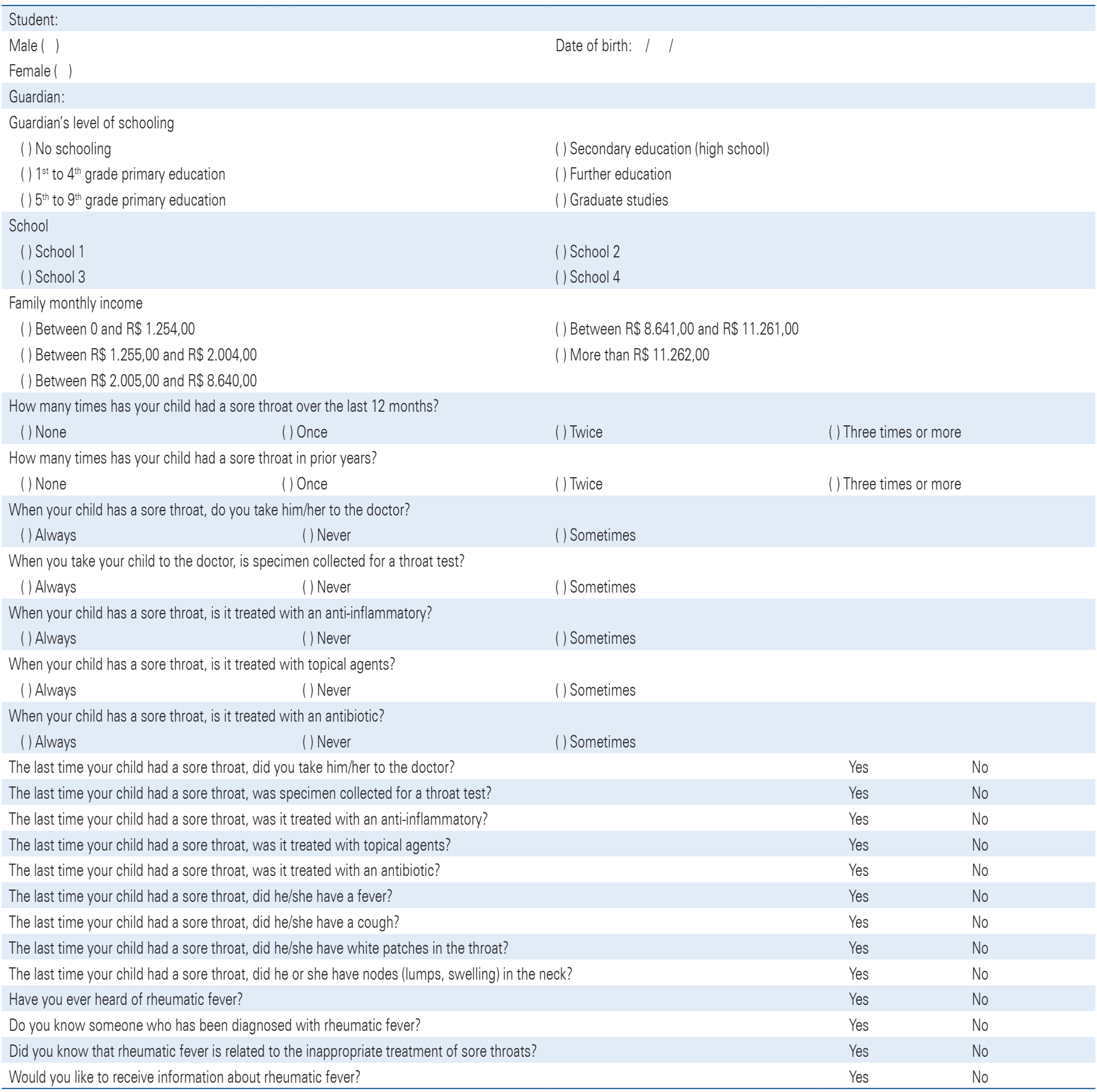

Among the students assessed, 75.2\% had had at least one episode of odynophagia in the previous 12 months. If the previous 2 years were considered, $89.8 \%$ reported this symptom. When analyzing the number of times the child had sore throat in the previous years, the most recurrent answers were three or more episodes (34.4\%) and two episodes $(33.10 \%)$.

As shown in table 3, the question "When you take your child to the doctor, is specimen collected for a throat test?" was the only question that had the highest percentage of response "never", with $67.8 \%$ among the Likert scale type questions. The questions "When your child has a sore throat, is it treated with topical agents?" and "When your child has a sore throat, is it treated with an antibiotic?" had as most prevalent answer "sometimes", with rates of $37.8 \%$ and $45.5 \%$, respectively. As for the questions "When your child has a sore throat, do you take him/her to the doctor?" and "When your child has a sore throat, is it treated with an anti-inflammatory?" they had the answer "always" as the most recurrent, with $47.1 \%$ and $43.0 \%$, respectively. 
Table 2. Relative frequency of demographic variables

\begin{tabular}{|c|c|c|}
\hline Variables & $\begin{array}{c}n=323 \\
n(\%)\end{array}$ & p value \\
\hline \multicolumn{3}{|l|}{ Sex } \\
\hline Female & $198(61.30)$ & \multirow[t]{2}{*}{$<0.001$} \\
\hline Male & $125(38.70)$ & \\
\hline \multicolumn{3}{|l|}{ School Network } \\
\hline Private & $74(22.90)$ & \multirow[t]{2}{*}{$<0.001$} \\
\hline State-owned & $249(77.10)$ & \\
\hline \multicolumn{3}{|l|}{ Guardian's level of schooling } \\
\hline No schooling & $5(1.50)$ & $<0.001$ \\
\hline $1^{\text {st }}$ to $4^{\text {th }}$ grade & $40(12.40)$ & $<0.001$ \\
\hline $5^{\text {th }}$ to $9^{\text {th }}$ grade & $78(24.10)$ & $<0.001$ \\
\hline Secondary education (high school) & $157(48.60)$ & Reference \\
\hline Graduate studies & $12(3.70)$ & $<0.001$ \\
\hline Further education & $31(9.60)$ & $<0.001$ \\
\hline \multicolumn{3}{|l|}{ Family monthly income } \\
\hline$R \$ 0.00-R \$ 1.254,00$ & $104(32.20)$ & 0.214 \\
\hline$R \$ 1.255,00-R \$ 2.004,00$ & $47(14.60)$ & $<0.001$ \\
\hline $\mathrm{R} \$ 2.005,00-\mathrm{R} \$ 8.640,00$ & $45(13.90)$ & $<0.001$ \\
\hline$R \$ 8.641,00-R \$ 11.261,00$ & $5(1.50)$ & $<0.001$ \\
\hline$>\operatorname{R} \$ 11.262,00$ & $3(0.90)$ & $<0.001$ \\
\hline Unwilling to inform & $119(36.80)$ & Reference \\
\hline \multicolumn{3}{|c|}{ How many times has your child had a sore throat over the last 12 months? } \\
\hline None & $80(24.80)$ & 0.079 \\
\hline Once & $100(31.00)$ & Reference \\
\hline Twice & $87(26.90)$ & 0.259 \\
\hline Three or more times & $56(17.30)$ & $<0.001$ \\
\hline \multicolumn{3}{|c|}{ How many times has your child had a sore throat in prior years? } \\
\hline None & $33(10.20)$ & $<0.001$ \\
\hline One & $72(22.30)$ & $<0.001$ \\
\hline Two & $107(33.10)$ & 0.739 \\
\hline Three or more & $111(34.40)$ & Reference \\
\hline
\end{tabular}

Tabela 3. Relative frequency of Likert-type

\begin{tabular}{|c|c|c|}
\hline Variables & n $(\%)$ & p value \\
\hline \multicolumn{3}{|c|}{ When your child has a sore throat, do you take him/her to the doctor? } \\
\hline Never & $24(7.4)$ & $<0.001$ \\
\hline Sometimes & $147(45.5)$ & 0.693 \\
\hline Always & $152(47.1)$ & Reference \\
\hline \multicolumn{3}{|c|}{ When you take your child to the doctor, is specimen collected for a throat test? } \\
\hline Never & $220(67.8)$ & Reference \\
\hline Sometimes & $56(17.3)$ & $<0.001$ \\
\hline Always & $48(14.9)$ & $<0.001$ \\
\hline \multicolumn{3}{|c|}{ When your child has a sore throat, is it treated with an anti-inflammatory? } \\
\hline Never & $47(14.6)$ & $<0.001$ \\
\hline Sometimes & $137(42.4)$ & 0.874 \\
\hline Always & $139(43.0)$ & Reference \\
\hline \multicolumn{3}{|c|}{ When your child has a sore throat, is it treated with topical agents? } \\
\hline Never & $106(32.8)$ & 0.188 \\
\hline Sometimes & $122(37.8)$ & Reference \\
\hline Always & $95(29.4)$ & 0.025 \\
\hline \multicolumn{3}{|c|}{ When your child has a sore throat, is it treated with an antibiotic? } \\
\hline Never & $43(13.3)$ & $<0.001$ \\
\hline Sometimes & $147(45.5)$ & Reference \\
\hline Always & $133(41.2)$ & 0.266 \\
\hline
\end{tabular}


In the question "The last time your child had a sore throat, was specimen collected for a throat test?", $83 \%$ answered "no." In contrast, regarding the question "The last time your child had a sore throat, was it treated with an antibiotic?" 63.2\% indicated "yes" (Table 4).

The majority had fever and cough associated with the condition (65.0\% and $62.5 \%$, respectively), and the minority had white patches in the throat and adenomegaly in the neck $(23.8 \%$ and $19.2 \%$, respectively).

When assessing the question "Did you know that rheumatic fever is related to the inappropriate treatment of sore throat?", $81.7 \%$ denied having such knowledge. The question "Would you like to receive information about rheumatic fever?" was answered affirmatively by $85.8 \%$.

\section{DISCUSSION}

Although the incidence of rheumatic fever is more significant between 5 and 15 years of age, the study included patients from a wider age range, with students aged up to 17 years. Moreover, although the incidence is lower than in the mentioned age group, it is not null between 15 and 17 years, and has epidemiological significance.

According to the 2018 School Census released by Inep, participation of state-owned schools in the municipality of Rio de Janeiro (RJ) accounts to $67.08 \%$, ${ }^{(8)}$ which is lower than in this study, in which $77.1 \%$ of students came from state-owned schools. In this group, there was a prevalence of guardian's schooling level up to high school, and low or not informed family monthly income. Thus, the restricted access to information reported in the study may reflect the socioeconomic panorama experienced by the families analyzed.

Sore throat is the second most common acute infectious manifestation observed by family physicians, and it is estimated that less than one in ten people with sore throat seek care. ${ }^{(9)}$ The high incidence of tonsillitis found in this study reflects such a panorama. When asked if they take their children to the doctor in case of sore throat, most said yes, showing a higher-thanexpected valuation of the episodes. In Brazil, rapid tests are rarely available in the public health services, ${ }^{(10)}$ justifying the low frequency of its performance found in this study and the diagnosis based exclusively on clinical criteria. Thus, it is possible to conclude that most patients are treated empirically or, possibly, only according to these criteria.

Among the treatments used, anti-inflammatory drugs and antibiotics stood out. Although $70 \%$ to $85 \%$ cases of acute pharyngotonsillitis are viral, ${ }^{(11)}$ which would not justify the use of antibiotics, its almost universal use seems to reflect the low specificity or lack of knowledge of currently used diagnostic criteria. The indiscriminate use of antibiotics may be advantageous, initially to reduce the incidence of rheumatic fever, but it probably implies in the selection of resistant strains.

In the Centor score ${ }^{(12)}$ used to guide the need for testing and treatment for group A streptococcal pharyngitis in patients with oropharyngeal pain, adenomegaly, and tonsillar exudate are parameters that add one point to the score. Presence of cough, on the other hand, reduces one point, since it is a characteristic

Table 4. Relative frequency of Yes/No

\begin{tabular}{|c|c|c|c|}
\hline Question & $\begin{array}{c}\text { Yes } \\
\text { n (\%) }\end{array}$ & $\begin{array}{c}\text { No } \\
\text { n (\%) }\end{array}$ & p value* \\
\hline The last time your child had a sore throat, did you take him/her to the doctor? & $223(69.0)$ & $100(31.0)$ & $<0.001$ \\
\hline The last time your child had a sore throat, was specimen collected for a throat test? & $55(17.0)$ & $268(83.0)$ & $<0.001$ \\
\hline The last time your child had a sore throat, was it treated with an anti-inflammatory? & $204(63.2)$ & $119(36.8)$ & $<0.001$ \\
\hline The last time your child had a sore throat, was it treated with topical agents? & $157(48.6)$ & $166(51.4)$ & 0.479 \\
\hline The last time your child had a sore throat, was it treated with an antibiotic? & $204(63.2)$ & $119(36.8)$ & $<0.001$ \\
\hline The last time your child had a sore throat, did he/she have a fever? & $210(65.0)$ & $113(35.0)$ & $<0.001$ \\
\hline The last time your child had a sore throat, did he/she have a cough? & $202(62.5)$ & $121(37.5)$ & $<0.001$ \\
\hline The last time your child had a sore throat, did he/she have white patches in the throat? & $77(23.8)$ & $246(76.2)$ & $<0.001$ \\
\hline The last time your child had a sore throat, did he or she have nodes (lumps, swelling) in the neck? & $62(19.2)$ & $261(80.8)$ & $<0.001$ \\
\hline Have you ever heard of rheumatic fever? & $157(48.6)$ & $166(51.4)$ & 0.479 \\
\hline Do you know someone who has been diagnosed with rheumatic fever? & $60(18.6)$ & $263(81.4)$ & $<0.001$ \\
\hline Did you know that rheumatic fever is related to the inappropriate treatment of sore throats? & $59(18.3)$ & $264(81.7)$ & $<0.001$ \\
\hline Would you like to receive information about rheumatic fever? & $277(85.8)$ & $46(14.2)$ & $<0.001$ \\
\hline
\end{tabular}


manifestation of viral infections. The fact that $62.5 \%$ reported coughing in the last episode suggests a higher incidence of viral infections. Despite this finding, most are treated with antibiotics.

Approximately half of the guardians had already heard of rheumatic fever, and many knew someone diagnosed with the disease. We observed that, despite the lack of knowledge on the part of the general population about the determinant factors for rheumatic fever, the diagnosis is sufficiently frequent so that is recognized, reflecting significant prevalence, functional repercussion, morbidity, and mortality in the young population. ${ }^{(13)}$

Few had prior knowledge of the relation between inappropriate treatment of streptococcic tonsillitis and rheumatic fever. The population's knowledge of rheumatic fever is very limited, and educational programs geared towards this topic may be beneficial in reducing the impact of rheumatic heart disease. ${ }^{(14)}$ Most of the guardians demonstrated interest in receiving information about rheumatic fever. In this way, it is possible to infer that the main factor for disinformation in the case of the disease under study is lack of dissemination of information to the population.

\section{CONCLUSION}

The results obtained by evaluating the complete questionnaires confirmed the high incidence of tonsillitis in our midst, and the lack of knowledge regarding its relation with rheumatic fever. It is vital that the guardians value the complaint of odynophagia in their children, always seeking the orientation of healthcare professionals, who should be able to make the correct diagnosis and guarantee appropriate treatment. This disagrees with the picture found in this study, with frequent use of anti-inflammatory agents.

Most guardians demonstrated no knowledge of the relation between tonsillitis and rheumatic fever. The development of public measures to broaden knowledge of the population and healthcare professionals about the disease is also crucial, for there to be a greater valuation of the acute infection, allowing greater epidemiological control and reduced incidence of complications.

\section{AUTHORS' CONTRIBUTION}

All authors participated in conception, revision, data analysis and final text writing.

\section{IAUTHORS' INFORMATION}

Goldenzon RV: http://orcid.org/0000-0003-3345-9064

Lucas TO: http://orcid.org/0000-0002-0727-4579

Roiseman MM: http://orcid.org/0000-0002-5317-9644

Rodrigues MC: http://orcid.org/0000-0001-6787-3824

Fonseca AR: http://orcid.org/0000-0002-3536-3552

Oliveira SK: http://orcid.org/0000-0002-2426-716X

Goldenzon AV: http://orcid.org/0000-0003-1810-4812

\section{REFERENCES}

1. Anjos LM, Marcondes MB, Lima MF, Mondelli AL, Okoshi MP. Streptococcal acute pharyngitis. Rev Soc Bras Med Trop. 2014;47(4):409-13. Review.

2. Branco CE, Sampaio RO, Bracco MM, Morhy SS, Vieira ML, Guilherme L, et al. Rheumatic fever: a neglected and underdiagnosed disease. New perspective on diagnosis and prevention. Arq Bras Cardiol. 2016;107(5):482-4.

3. Watkins DA, Johnson CO, Colquhoun SM, Karthikeyan G, Beaton A, Bukhman $\mathrm{G}$, et al. Global, regional, and national burden of rheumatic heart disease, 1990-2015. N Engl J Med. 2017;377(8):713-22.

4. Santos JP, Carmo GA, Beaton AZ, Lourenço TV, Diamantino AC, Nunes MD, et al. Challenges for the implementation of the first large-scale rheumatic heart disease screening program in Brazil: the PROVAR study experience. Arq Bras Cardiol. 2017;108(4):370-4.

5. Ralston J, Reddy KS, Fuster V, Narula J. Cardiovascular diseases on the global agenda: the United Nations high level meeting, sustainable development goals, and the way forward. Glob Heart. 2016;11(4):375-9. Review.

6. Bertoletti JC. Profilaxia da febre reumática: quando e como fazer. Rev Soc Cardiol Rio Grande do Sul. 2004;13(1):1-2.

7. Ashurst JV, Edgerley-Gibb L. Streptococcal pharyngitis. StatPearls Publishing. In: StatPearls. Treasure Island (FL): StatPearls Publishing; 2021.

8. Brasil. Ministério da Educação. Instituto Nacional de Estudos e Pesquisas Educacionais Anísio Teixeira (INEP). Consulta matrícula. Brasília (DF):INEP. 2020 [citado 2021 Jan 10]. Disponível em: https://inepdata.inep.gov.br/ analytics/saw.dll?dashboard

9. Worrall GJ. Acute sore throat. Can Fam Physician. 2007:53(11):1961-2.

10. Sih TM, Bricks LF. Optimizing the management of the main acute infections in pediatric ORL: tonsillitis, sinusitis, otitis media. Braz J Otorhinolaryngol. 2008;74(5):755-62. Review.

11. Nascimento-Carvalho CM, Marques HH. The Brazilian Society of Pediatrics, Department of Infectious Diseases guidelines for the management of children and adolescents with acute pharyngitis. J Pediatr (Rio J). 2006;82(1):79-80; author reply 80-2.

12. Fine $A M$, Nizet $V$, Mandl KD. Large-scale validation of the Centor and Mclsaac scores to predict group A streptococcal pharyngitis. Arch Intern Med. 2012;172(11):847-52.

13. Zühlke LJ, Steer AC. Estimates of the global burden of rheumatic heart disease. Glob Heart. 2013;8(3):189-95.

14. Oliveira KK, Nascimento BR, Beaton AZ, Nunes MC, Silva JL, Rabelo LC, Barbosa MM, Oliveira CM, Mata MD, Costa WA, Pereira AF, Sable CA, Ribeiro AL; PROVAR (Programa de Rastreament0 da VAlvopatia Reumática e outras Doenças Cardiovasculares) investigators. Health education about rheumatic heart disease: a community-based cluster randomized trial: rheumatic heart disease educational strategies. Glob Heart. 2020;15(1):41. 